\title{
バイリンガルテキスト兼ビデオを用いた 医療受給者および供給者向け双方向型学習システム制作の試み
}

\author{
○塩澤友規 ${ }^{1,3}$, 佐藤隆巧 ${ }^{2,3}$ \\ ('日本大学医学部社会医学講座衛生学部門, 2 ハーバード大学病院リスクマネージメント財団) \\ ( ${ }^{3}$ ハーバード大学医学部マサチューセツエ科大学健康科学技術部門)
}

\begin{abstract}
A Bilingual Text and Digital Video Based Interactive Learning System
for Patients and Care Providers

Tomoki Shiozawa ${ }^{1,3}$, Luke Sato ${ }^{2,3}$

'Department of Environmental Health and Preventive Medicine

Nihon University School of Medicine

${ }^{2}$ Risk Management Foundation, Harvard Medical Institutions

${ }^{3}$ Harvard Medical School and Massachusetts Institute of Technology

Division of Health Sciences and Technology
\end{abstract}

\section{1. 緒言 :}

米国では，近年，所謂マイノリティの人ロが増 加の一途を辿り，中でもヒスパニック系市民のそ れが著しい (対総人口率 : 1980 年 $6.4 \%, 1990$ 年 $9.0 \%, 2000$ 年 $12.5 \%)^{1)}$. 新たに増加した市民の多 くは移民であり，その大多数が英語をうまく使い こなせない (対総人口率 : ヒスパニック系 $2.0 \%$, 他のマイノリティを含めた総数 $2.9 \%, 1990$ 年) $)^{1)}$. 彼等が医療受給者になった際，一方で彼等を指導 する医療供給者が不足なために，円滑な医療行為 は妨げられ, 社会問題化が起こっている. ハーバ ード大学病院では, この状況に対応する一策とし て, マルチメディア教育システムを試作している. Brigham and Women's 病院 (BWH) の産科新生児 科病棟には，スペイン語のみを話す母親が多数入 院している.ここでは，彼女等と，彼女等の新生 児授乳ケア教育を担当する看護師達を対象とし た教育用のマルチメディアシステム(MMS)につ き紹介する.

\section{2. 方法・結果 :}

編集 : 基盤となる資料として, BWH 患者教育ビデ 才図書館に所蔵される授乳指導用教育ビデオの英 語版およびスペイン語版を用いた，各々の内容を 吟味し, 双方の内容で関連または一致する部分を
選択した後, それ等の内容をテーマ別に分類した. 分類した各々のテーマを, 学習項目別に更に細項 目化，編集した．これ等の細項目部分のビデオを 各々デジタル変換した後, QuickTime ムービーと して保存した. ビデオ内の音声ナレーションによ る説明文を文字化し，テキストファイルとして保 存した.

デザイン : スクリーンサイズは $640 \times 480$ ピクセ ルのコンピュータ画面仕様とした. レイアウトは 出来るだけ単純性を心がけ, スイッチボタン類は, タッチスクリーン化への対応に備え, 大きなもの にした. 内容は, 二ヶ国語学習部分と小テスト部 分の 2 大項目に分類した.

ニヶ国語学習部分 : 同部分は, 前述の如く, 6 つの 小テーマに分類した. 各々の小テーマを, 学習項目 別に更に細項目化し，この各々が，音声ナレーシ ヨン付きのデジタルビデオと英語またはスペイン語 による字幕を伴う形とした. 英語版とスペイン語版 の間の往来を可能にするスイッチボタンを作成した. ビデオはテレビスクリーン形式で写し出され, 制御 ボタンによって, 再生, 繰り返し再生, 部分飛ばし, 或いは同じテーマの中で目的の部分に跳矔させるこ とができる様にした. テキスト字幕は, 制御盤の下 の文字盤に表示させた(Fig. 1).

小テスト部分 : 利用者が上記細項目の中で学んだ 
構文, 単語の意味の理解度を, 素早く自己評価出 来る様デザインした. “sentence jumble” (Fig. 2)は, MMS に特有な双方向的操作により，スペイン語 或いは英語の文を, 正しく構成することを可能に している. 単語の組み合わせ作業により，利用者 が, 単語の正しい意味を理解出来る様にしている.

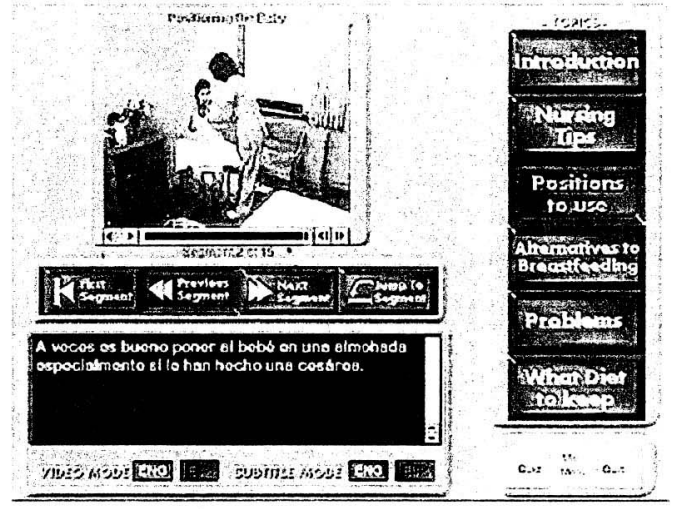

Fig. 1: The bilingual learning section

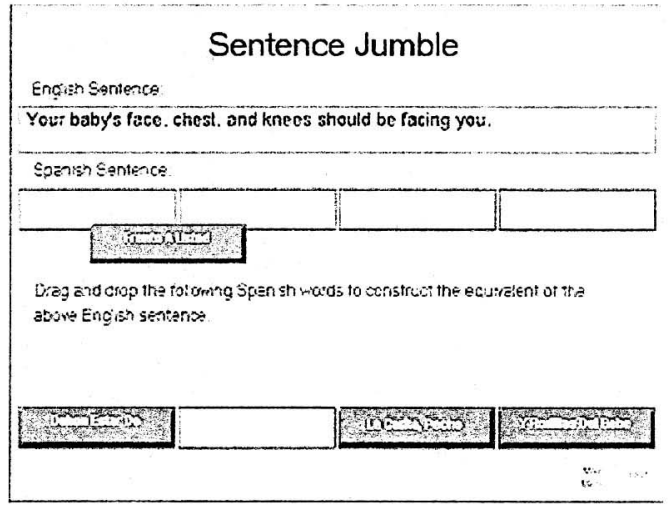

Fig. 2: The sentence jumble

制作ツール : 本システムは, 商業ベースの MMS 制作ソフト Authorware (Macromedia Inc.)を用いて 制作した. 制作過程では Macintosh を使用したが， 本システムの稼動環境としては, MS-Windows お よび Mac/OS 環境の双方で使用可能なバージョン を制作した.

\section{3. 考察 :}

MMS は，パーソナルコンピュータの普及と共 に大衆化されて既に久しく，現在では社会に深く 浸透した珍しくない存在である. その双方向性や 簡易・迅速性，また，ビデオ，音声，画像，文字 等の多角的な情報供給が，ヒトの意識に深い浸透 効果をもたらし，一般に，教育目的のツールとし
ては，文字やビデオ等の単一かつ一方向性の情報 提供法に比べ，より優れた点が多いと考えられて いる. MMS は，派生する疑問への回答に制限が あることが欠点ではあるが，逆に，教育内容の範 囲が予め決まっている場合には，その威力を発揮 すると思われる.

本システムの導入により期待される医療現場 への効果としては，(1)患者教育を行う人員の削減， (2)患者教育を行う人員の教育を行う人員の削減, (3)指導内容に対する患者の誤解を减少させ，将来 的に事故や訴訟の危険度を低下させ得るリスク マネージメント的効果, 等が挙げられる. しかし， 現段階に於いて，本システムは，その有用性につ き，詳細な評価を受けるまでには至っておらず， この点については今後の課題と考えている. 特に, 上記小テスト部分に関しては，言語教育を専門と する研究者の助言を仰ぐ等, 更なる検討の余地が 多く残されており，システム評価を行う以前の状 況と考えている.

ここ十数年来, 米国の人口の動向同様, 日本の 在留外国人数は急速に増加している. 外国人登録 者数は, 1988 年 94 万人から 1998 年 151 万人と, 10 年間で $61 \%$ 増加し ${ }^{3)}, 2000$ 年末には総人口の 1.33\%を占めるに至っている ${ }^{3)}$. また, 増加した在 留外国人は主に非永住者，つまり新たな移住者で あり ${ }^{3)}$ ，一般に日本語能力は不十分である.一方， 実際に日本語学習を行っている者は, 1988 年 64 千人, 1998 年 83 千人と ${ }^{4)}$, 在留外国人総数に比 べて増加率が低い，米国ほど深刻な状況とはいえ ないまでも; 我が国の医療現場に於いても同様の 問題が生じつつある状況にあると言える. 本シス テムは，これに応えるツールとして参考になるも のと思われる.

\section{参考文献 :}

1) U.S. Bureau of the Census: The Hispanic Population 2000, 2001.

2) U.S. Bureau of the Census: Language Use and English Ability, 1990.

3) 法務省: 平成 13 年度在留外国人統計, 2001

4) 文化庁: 平成 10 年度日本語教育実態調査, 1998 